\title{
DETERMINATION OF THE MINIMUM WAGE OF PALEMBANG CITY IN 2019 IN SYARIAH ECONOMIC PERSPECTIVE
}

\author{
Hana Pertiwi ${ }^{1}$
}

\begin{abstract}
Islam commands people to seek a job in meeting the needs of life, in way can benefit those who seek. in this research is the study subject " minimum wage in the city of palembang in 2016 sharia economic perspective" the formulation of the problem how the principles remuneration according to shariah economics, how the mecanism for setting the minimum wage the city of palembang in accordance with economic prinsiple, and what are the implications for the welfare of the city minimum wage workers in the city of Palembang. This research is a field research, which was conducted using qualitative. The source of this study are primari and secondary. Techniques in this study is observation, interview and documentation. The method used in this research is normative juridical approach that is supported by empirical juridical approach.
\end{abstract}

Keywords: wage,islamic law, welfare of humen life.

\section{The Introduction}

Problems that arise on the surface today in the world of labor are problems related to the fulfillment of workers' rights, first of all the right to be treated properly in a work environment, the right to social security and the right to a decent wage. employers or employers who sometimes behave inhumanely towards workers.

To fulfill the needs of human life, workers carry out their activities based on what has become their responsibility as laborers or employees, but sometimes what has been done is not in balance with what is obtained. So that they cannot fully meet the needs of life. Workers have the right, namely to get a job, the right to wages in accordance with the agreement, be treated well in the work environment, the right to social security (Lubis, 2014; 166). The main points of workers' dissatisfaction with wages include the slow payment of wages, the deductions of wages for the needs of and for the interests of workers, without prior negotiation with the workers, the willingness of the workers so that their wages are equal to better wages than other companies.

The workers consider that their current living conditions are still apprehensive. They think that the wages they receive are not in accordance with the demands and rights of workers. Even the minimum wage received is difficult to meet the basic needs of workers and their families on a daily basis. Even though the annual minimum wage has increased, it still does not meet the basic needs of workers and their families. Reporting from Indozone, the minimum wage Palembang City (UMP) for South Sumatra in 2020 was stated to have been approved worth Rp3,043,111, an increase of $8.51 \%$ from the 2019 UMP which was Rp2,805,751. For Palembang City, the 2020 city minimum wage (UMK) is set at IDR 3,165,519 per month with a

Fakultas Syariah dan Hukum UIN Raden Fatah Palembang, Email: hanapertiwi_uin@radenfatah.ac.id 
standard of 7 (seven) working hours a day and or 40 (forty) working hours a week. (Https://www.indozone, 2020).

The workers feel that their position continues to be marginalized, the role of workers is still limited to an instrument of the production element in the economic system. With the minimum wage continues to increase in accordance with the development of people's purchasing power. However, this percentage increase in wages does not have a strong correlation with increasing the needs of labor and society (Iskandar, 2004; 84).

Restrictions on the supply of each level of quality of labor compared to all other production factors are expected to increase wages, the addition of labor in other cases is constant, tends to push the wage level down (Khalid, $1986 ; 281$ ). Thus wage setting can be carried out based on existing provisions. applicable and able to meet the proper needs of workers / labor.

Since the enactment of Regional Autonomy in accordance with the provisions Law Number 32 of 2004 concerning Regional Government, and in accordance with the provisions of article 1 number (3) Regional government is the Governor, Regent or Mayor, and regional apparatus as elements of regional government administration, number (5) Regional autonomy is the right, authority and obligation of the autonomous region to regulate and manage government affairs and the interests of the local community in accordance with statutory regulations, (7) Decentralization is the handover of governmental authority by the Government to autonomous regions to regulate and manage government affairs in the system. The Unitary State of the Republic of Indonesia.

With regard to decentralization in regional autonomy, including manpower issues as regulated in article 13 Law Number 32 of 2004 paragraph (1) letter (h) Mandatory affairs that fall under the authority of provincial government are affairs on a provincial scale which include: crossregency manpower services/City. Meanwhile, the content of Article 14 paragraph (1) letter (h), the mandatory affairs which become the authority of the regional government for the Regency/City are the affairs of a Regency/City scale covering: manpower sector services.

Islamic law also regulates the wages of workers in the concept of Ijarah. Ijarah There are two kinds of in Islam, namely Ijarah for use and Ijarah for work. Here the author discusses Ijarah to work because it involves the wages given. For example, ijarah for a certain job such as hiring someone to build a building, hiring someone to sew clothes, hiring someone to transport goods to a certain place, hiring someone to dye cloth, hiring someone to repair shoes and so on in the form of jobs that may pay someone to do it.

The minimum wage for Palembang City is determined by the industrial relations sector, working conditions and worker welfare. Research on the mechanism for determining the minimum wage in Palembang City was carried out by collecting data/documents through interviews with predetermined informants and conducting field observations. It is intended that the results of this analysis can be directed and can find solutions to the problem of determining the minimum wage in Palembang City from a sharia economic perspective. 


\section{Research methods}

Type of data in this study is qualitative data, namely data collection in a natural setting, using natural methods, and carried out by people or researchers who are naturally interested (Tohirin, 2012; 2). The research method used to examine the condition of natural objects where the researcher is the key instrument (Riduwan, 2005; 51).

Data sources This study is primary and secondary. Primary data is obtained from direct interviews with research subjects, such as laws, government regulations. As for secondary legal data, namely everything that provides an explanation of primary legal materials, such as draft laws, books, research results, newspapers, magazines, literature and the internet. Data Collection Techniques is observation, Interview, and Documentation.

The research was located in the city of Palembang, South Sumatra province, meanwhile, the reason the researchers took Palembang city as the research area was that the city of Palembang was one of the autonomous regions that had full authority to regulate its own governance. Including the determination of the Provincial Minimum Wage (UMP) for Palembang City.

\section{Discussion and Results \\ Wages}

Wages come from the word "al-ajru" which means "al-iwadlu" (change), wages or rewards (Sabiq, 1987; 5, see also Ghazaly2010; 277). According to Afzalurrahman (Afzalurrhman, 2000; 295) wages are the price of labor paid for services in production. Meanwhile, Hafiduddin and Tanjung stated that wages are rewards received by someone for the form of work in the form of material rewards in the world (fair and proper) and in the form of rewards in the afterlife (better rewards). In Islam wages are an element of ijarah. Some scholars, namely Shafi'i, Hanafi, and Hambali, do not differ in the definition of ijarah, which is a transaction of a benefit with a certain reward and nature. The concept of wages appears in the ijarah contract, namely the possession of services of a ajir (the person contracted for labor) by musta'jir (the person who contracts the labor), in addition to three other elements: aqid (people who have contracted), ma'qud'alaih (goods which is the object of the contract), and benefits. Ijarah is a transaction for certain services accompanied by compensation. Compensation for these benefits is in the form of al-Ujrah (wages) (Mas'adi, 2002; 182). In the terminilogy of Fiqih Muamalah, compensation in transactions between goods and money is called tsaman (price), while money transactions with human labor are called ujrah (wages) (Anto, 2003; 224).

Based on the provisions of Article 1 number 30 of Law Number 13 of 2003, which reads: "Wages are the rights of workers/laborers that are received and expressed in the form of money as compensation from the entrepreneur or employer to workers/laborers who are determined and paid according to an employment agreement, agreements, or statutory regulations, including allowances for workers/laborers and their families for a job and / or service that has been or will be performed" (Asri, $2009 ; 107)$.

Another definition states that the terms (wage) and salary (salary) describe the great variety in payment methods. In common usage, wages are 
payments made to production employees on the basis of long hours worked. Salary is a payment given to administrative, supervisory and managerial employees. Wages are paid to those who usually do not have guaranteed employment continuously throughout the week, month or year. Salary is a service fee that is paid or calculated on a monthly or annual basis (Moekijat, 1987; 6.). This difference is not absolute in recent years as some companies have paid salaries to permanent or non-probation employees. Income is the actual wage minus overtime, fees, commissions and other factors.

It can be concluded that wages are rewards in the form of money given to workers who have fulfilled their obligations for survival.

\section{Islamic Law and the Benefits of Human Life}

The 'urf according to syara' in the study of ushul fiqh is a community habit that can be obeyed in their lives so that they feel at ease. Longstanding habits can be in the form of words and deeds, both specific and general in nature (Khallaf, 2000; 123). 'urf is something that has become a habit and is accepted by good character and does not conflict with Islamic law.

If we look at the historical approach at the time of the Prophet and his companions, of course 'urf already exists even though only substantially and has not been formulated as a theory. 'Urf only began to find its form during the time of the Imam Hanafi, Imam Maliki, Imam Shafi'i and Imam Hambali. The use of 'urf' was explicitly used by two imams before Imam Shafi'i, namely Imam Hanafi and Imam Maliki. (Harun \& Fauziah, 2014: 23).

In terms of determining wages, Islam does not set a specific price in the wages of a worker, but these efforts must fulfill the rights of justice and must also pay attention to the quality of work, interests and size without excessive mistakes in it (U'qlah; 60). Wages are muamalah that has been stated in Islam, the original law according to the number of scholars is permissible or permissible in accordance with the provisions stipulated by the syara 'based on the Koran, hadith and the provisions of the scholars (Ghazaly, 2010; 277. See also Wahbah al-Juhaili , 2005; 3801-3802).

The purpose of syari in determining Islamic law is to realize the benefit of humans by ensuring their basic needs (dharuriyat) and fulfilling their secondary needs (hajiyat), as well as their complement (tahsiniyat) (Khallaf, 2000; 319). According to al-Syatibi, to classify all needs in Islamic studies related to and the creation of the benefit of religion and world life, including the category of mubah, divided into dharuriyah, hajiyat, and tahsiniyat.

According to al-Ghazali, human needs consist of three, namely primary (dharuriyat), secondary (hajiyat), and luxury equipment (tahsiniyat) (Zainidin, 2008; 44, see also Syaifullah, 2008; 7). Thus it is clear that there is a need for primary (dharuriyat), secondary (hajiyat), and luxury equipment (tahsiniyat) needs. The provisions of the Palembang City Minimum Wage and the mechanism for determining it in the view of Islamic law are applications of maslahah and urf theories.

The theory of maslahah as a reference for determining the minimum wage of Palembang City means that there are no texts from the al-Qur'an and as-Sunnah that explain wages textually. But based on the approach to 
the passage of syar'i law, namely maintaining the objectives of Isalm law based on maqasid al syari'ah which has the main goal of presenting maslahah, namely the good and welfare of humans. Wages are a manifestation of maintaining wealth (al-mal) in al-dharuriyah al-kams. Then the form of maslahah is implemented in the Minimum Wage provisions in Government Regulation Number 78 of 2015 concerning wages, namely the determination of wages is carried out based on national inflation and gross domestic product growth, economic growth as well as a comparison of Decent Living Needs (known as Kebutuhan Hidup Layak and abbreviated KHL). In Islam, wages are one of the elements of ijarah besides the three elements of aqid (people who have contracted), ma'qud (items that are the object of the contract), and benefits. Then the concept of wages in Islam uses a morality frame. Wages must be balanced between the world and the hereafter in that the determination must be in accordance with what is done, Islam wants a person to work to receive a decent wage, not less than his daily needs.

So before working there needs to be an agreement between the two parties so that there is no dispute between the two. The Muslims at the time of the companions believed that Ijarah was permissible, because humans needed the benefit of an item such as their need for the item itself. However, syara 'is a number of guarantees for the rights of ajiir (people employed for wages), namely willingness and agreement, justice or professionalism, and urf (the prevailing custom, common law). Therefore, wages are fair in accordance with prevailing custom by considering the form of expertise, and should be conducted on basic freedoms, and the willingness of their own accord without some form of compulsion (Zuhaili, 2011; 84).

Syariat Islam recommends that the wages received by workers are in accordance with the workforce that has been given. Manpower should not be harmed, deceived and exploited, because considering the social condition of the workforce is in a weak economic position. Salaries must be paid or rewarded according to expertise and the skills of each worker.

In determining the minimum wage, there are principles which, according to Moekiyat, can be used as a basis for consideration in determining the amount of the minimum wage:

a. The wages given must be sufficient for the life of the workers and their families, in other words, the amount of wages must meet the minimum needs.

b. Paying wages must be fair, meaning that the amount of wages must depend on the severity of the obligations and responsibilities imposed on the worker concerned. Workers whose jobs are difficult for heavy responsibilities must be paid a higher wage than workers/laborers whose responsibilities and responsibilities are light.

c. Wages must be given on time, in order to reduce work productivity.

d. The size of the wages must follow the development of market prices, this needs to be considered because what matters to workers is not the amount of money received but how many goods and services can be obtained with these services. So the most important thing is real wages not nominal.

e. The wage payment system must be easy to understand and implement so that payments can be made in a relatively short time. 
f. The difference in wage rates should be based on an objective job evaluation.

g. The wage structure should be reviewed and possibly improved if conditions change.

Islam offers a good solution to the problem of wages and saves the interests of two parties, namely workers and entrepreneurs. In this case there are several things that must be fulfilled in relation to the problem, namely the principles of justice, worthiness, and virtue.

The main principle of justice lies in the clarity of aqad (transaction) and the commitment to do so. Aqad in labor is aqad that occurs between workers and employers. This means that before workers are hired, it must be clear how the wages that workers will receive. The wages include the amount of wages and the procedure for paying wages. Specifically for the method of paying wages, the Prophet said as narrated by Ibn Majah and Imam Thabrani: (Mansyur, 1992; 515). "From Abdillah bin Umar, Rasulullah Saw. Said: "Give the wages of a hired man before his sweat dries".

In explaining the hadith, Syeikh Yusuf Qardhawi in his book Message of Values and Morals in the Islamic Economy, explains as follows: "In fact, a worker is only entitled to his wages if he has fulfilled his work properly and in accordance with the agreement, because Muslims are bound with the conditions between them except the conditions that prohibit the lawful or justify the haram. However, if he is absent from work without the right reason or deliberately fulfills it improperly, then it should be taken into account (his wages are deducted) because every right is accompanied by an obligation. As long as he is fully paid, his obligations must also be fulfilled. This should be explained in detail in the "work regulations" which explain the respective rights and obligations of both parties. Thus, wages must be fair, according to the agreed provisions and no one is hurt between the worker and the wage provider so that it can provide benefits. between one another" (Yusuf Qhardhawi).

Whereas Feasibility demands that the work wage is sufficient to meet the minimum living needs in a decent, proper manner means sufficient food, shelter and shelter, meaning that the wage must meet the minimum needs of the three needs which are dharuriyat, or basic needs. The fulfillment of basic human needs is a basic wage system which humane, namely the minimum basic needs which include A. Basic needs for life, food, clothing and shelter, water, air, fuel, etc. B. Needs that support community welfare and increase individual capacity/productivity, education, services, health, facilities communication, transportation, social institutions, freedom of opinion, the availability of markets etc. C. The need to increase access (opportunity to get something) to production methods and economic opportunities, the country. Vegetation, capital including technology, job opportunities and a decent income. D. The need to live in security and freedom to make decisions, respect for HAM, participation in politics, security and social defense, laws and regulations that are fair to all levels of society (Sudjana, 2000; 35-36).

Worth meaningful according to the market. Islam wants a worker to receive a decent wage, not less than his daily needs. And in accordance with the consumption habits of the people at that time (U'qlah Al-Ibrahimi, 1988).

The government sets the minimum wage as referred to in article 88 paragraph (3) letter a of Law Number 13 of 2003 concerning manpower based 
on the needs of a decent life and takes into account productivity and economic growth. In article 89 of Law Number 13 of 2003, the minimum wage consists of the minimum wage based on the province or district/city area and the minimum wage based on the sector in the province or district/city.

Whereas the next principle is the principle of virtue, which means demanding that the services rendered bring huge profits to workers so that they can be given bonuses. In the agreement both parties are warned to be honest and fair in all their affairs. so that no acts of persecution that harm the interests of entrepreneurs and labor.

Based on the description above, it can be concluded that in order to maintain wages at a reasonable standard, Islam provides complete freedom in labor mobility in accordance with the agreed agreement (contract). So that the partnership relationship can run well and all parties involved benefit from each other, Islam regulates it clearly and in detail with the laws relating to ijaratul ajir (work contracts). This arrangement includes the stipulation of Islamic provisions in the work contract between employers and workers, with due regard to the principles of justice, worthiness and virtue.

\section{Profile of Palembang City}

As a trading city, a commercial city and is now increasing become an industrial city, a place for tin, coal, a city of oil, namely energy materials which lately have confirmed its characteristics as tough factors scare off the international world (Akib, 1975; 2). Palembang is a Metropolis City which is divided into two parts by the Musi River namely Palembang Ulu and Palembang Ilir.

Palembang City as the capital city of South Sumatra Province, is located at positions 104 ' 37 ' - 104 '52' East Longitude and 2 '52' - 3 '05' South Latitude, the area of Palembang City is approximately $400.61 \mathrm{Km}^{2}$. The position of Palembang City is very strategic because it is traversed by a national cross-road, namely the Sumatra highway that connects from Sabang (Aceh) to Bakauheni (Lampung) as the entrance gate for migrants from Java Island. The administrative boundaries of Palembang City include: (Municipal Government of Palembang, 1997; 4-5)

a. North ; borders with Banyuasin Regency

b. East side; borders with Banyuasin Regency

c. West Side; borders with Banyuasin Regency

d. South side; borders with Ogan Komering Ilir Regency

The population of Palembang City has always increased from year to year. This is because the city of Palembang is the capital of the province where the center of economic activity is growing rapidly. Population is a very important supporting factor in determining the success or failure of government programs.

\section{Indicators for Determination of Wages}

In accordance with the mandate of Article 97 of Law Number 13 of 2003 concerning Manpower, on October 23, 2015 government regulation number 78 of 2015 concerning wages has been stipulated Government Regulation Number 78 of 2015 concerning Wages and promulgated in the State Gazette of the Republic of Indonesia Year 2015 Number 237, State 
Gazette of the Republic of Indonesia No. 574 . This government regulation is one of the government's agendas in order to provide protection of rights to wages for workers/laborers and certainty of doing business for entrepreneurs and to realize fair wages.

Factors considered in determining the minimum wage for Palembang City are Decent Living Needs (KHL) and Economic Growth. Decent Living Needs (KHL) is the standard required for a single worker/laborer to be able to live properly physically within 1 month. (Regulation of the Minister of Manpower of the Republic of Indonesia Number 21 of 2016 concerning Decent Living Needs). KHL component is one of the considerations in determining the minimum wage starting in 2006, the KHL component report is made every 1 month by the Palembang City Disnaskertrans and proposed to the South Sumatra Provincial Disnskertrans and submitted to the governor.

Data regarding the current year's national inflation rate and the current year's gross domestic product (known as Produk Domestik Bruto and abbreviated PDB) growth used to calculate the 2016 minimum wage are sourced from the central statistics agency (known as Bahan Pusat Statistic and abbreviated BPS), namely: National inflation rate of $6.83 \%$ (six point eighty three percent), GDP growth of $4.67 \%$ (four point sixty seven percent).

When the positive law states that the component of decent living needs of labor is based on the calculation for single workers in a month with 3,000 calories per day. With seven components, namely food and drink, clothing, housing, education, health, transportation and recreation and entertainment. In the Islamic view, basic needs are guaranteed by the State. Because Islamic law guarantees its existence, because wages are part of the protection of property (al-mal), every individual and society has an obligation to maintain its existence.

Based on this, a living wage is a wage that creates a prosperous individual and society. The concept of a prosperous society in an Islamic perspective is inseparable from the discussion of maqasid al-sharia. Which also has the main objective of presenting maslahat for the salvation of 5 (five) main things that are covered in al-dharuriyah al-khams. Namely religion (aldin), soul (al-nafs), reason (al-aql), katurunan (al-nasl), and property (almal), each of which is related to human needs that must be fulfilled, so that the safety of these five things is maintained (Syifullah, 2008; 54).

\section{Provisions for the Minimum Wage of Palembang City in Fulfilling the Needs of a Decent Life for Workers in Palembang City According to Islam.}

Wages are one of the indicators of human welfare, namely the main component in meeting the daily needs of workers/laborers. In Islamic political economy, it is stated that there is a guarantee that the fulfillment of all the primary needs of each person as a whole is guaranteed (Maghfur Wachid, 2009; 52).

Employers who will employ a worker must first explain everything related to the work to be carried out, including time, type of work and wages. stipulation of provisions governing the settlement of disputes that occur between employers and workers. Including provisions regulating how to deal with injustice committed by one party (employers and workers) against another party. 
Likewise, employers are obliged to pay workers' wages and respect work transactions that have been determined, based on applicable laws and cannot act arbitrarily towards workers.

Islam as a religion that is universal and as rahmatan lil'alamin not only regulates vertical relationships it also regulates horizontal relationships. Which balance the needs of life in this world and the hereafter. Islam in this connection introduces humans to the five components of life which are of interest to all humans. Islamic law thus functions to maintain five basic components, namely soul, mind, property, harmony and human religious belief (Yafie, 2003; 4).

There are several provisions that will guarantee the treatment of labor humanely, namely: (Anto, 2003; 228)

a. The building of the relationship between mu'ajir and ajir is a human brotherly relationship, so this relationship is a man to man, brotherly relationship, not men to material relationship.

b. The workload and the environment that surrounds it must pay attention to human values, even humans also need certain times to rest, relax and socialize with their environment. There is a guarantee to carry out worship.

c. The minimum wage level should be sufficient to fulfill the basic needs of the workforce. The higher the wage level, of course, the better for the welfare of the workforce.

With the existence of wages, individuals are able to pay for their daily needs, be able to buy goods and services they need and carry out their economic activities both for worldly and for the hereafter. In setting wages, Islam has the main values in obtaining property. Islam emphasizes that there are ways of relationship between employers and workers in accordance with the shari'ah, namely towards the establishment of mutual benefit. Benefit all parties without being wronged. Meanwhile, Islam views the relationship between workers and employers as a partnership relationship that has a common goal, to get the same benefits and justice.

When the law is positive, it states that the component of the living needs of workers is based on the calculation for single workers in a month with 3,000 calories per day. With seven components, namely food and drink, clothing, housing, education, health, transportation and recreation as well as entertainment. In the Islamic view, basic needs are guaranteed by the State. Because Islamic law guarantees its existence, because wages are part of the protection of property (al-mal), every individual and society has an obligation to maintain its existence.

According to Drs. Alisani Indra. Msi. as the head of the section on industrial relations, working conditions and worker welfare, he stated that the mechanism for determining the minimum wage in Palembang city is: At first the regional wage council (known as Dewan Pengupahan Daerah and abbreviated DPD) consists of bureaucrats, academics, laborers, and employers to hold a meeting to form a survey team and go down. the field of finding out the price of a number of needs required by employees and laborers. After a survey to several markets in Palembang, which were considered representative, it was found that the number of decent living needs was used as the basis for determining the minimum wage based on decent living needs (KHL), apart from being viewed from economic growth 
and inflation data. The Regional Wage Council (DPD) proposes the City Minimum Wage to the governor to be ratified, KHL component is used as one of the bases for determining the minimum wage based on the lives of single (unmarried) workers apart from statistical data (Inflation Data) and Economic growth".

The same thing was expressed by Hermansyah as the main director APINDO regarding the wage mechanism. He also stated that: "In general, now the determination of the UMP refers to Law No. 13 on employment and PP No.78". Also explained by Mr. RM Edi Ali, SH as the head of the provincial wage division. Explains: "The mechanism for determining city wages is the same as the mechanism for determining the province as stipulated in Presidential Decree no. 107 of 2004 concerning Wage Councils, the institution of the Wage Councils consists of the National Wage Council (known as Dewan Pengupahan Nasional and abbreviated Depenas), Provincial Wage Council (known as Dewan Pengupahan Propinsi and abbreviated Depeprov) and District/City Wage Council (known as Dewan Pengupahan Kabupaten/Kota and abbreviated Depekab/Depeko). And the mechanism for determining the minimum wage in the city of Palembang is carried out based on PP No. 78 of 2015.

Based on this, a decent wage is a wage that creates a prosperous individual and society. The concept of a prosperous society in an Islamic perspective is inseparable from the discussion of maqasid al-sharia. Which also has the main objective of presenting maslahat for the safety of 5 (five) main things that are covered in al-dharuriyah al-khams. Namely religion (aldin), soul (al-nafs), reason (al-aql), descendants (al-nasl), and property (almal), each of which is related to the minimum needs that must be met, so that the safety of these five things is maintained (Syifullah, 2008; 54).

\section{Implications of Minimum Wages Palembang City on Workers' Welfare}

The real problem of labor is not only limited to wages, it is much more about the welfare problems that are given to workers in power. Welfare (maslahah) in this case is one's attainment to a standard level of fulfillment of needs no less and no more, so that the pattern of life becomes stable with the achievement of maslahah. According to al-Ghazali, the welfare (maslahah) of a society depends on the search and maintenance of five basic goals, namely religion (ad-dien), life or soul (nafs), family or descent (nasl), property or wealth (maal), and intellect or reason (aql). He emphasized that according to the demands of the revelation, the goodness of the hereafter is the main goal (Karim, 2011; 62. see also Abu Hamid al-Ghazal, 2; 109). 
Table 1: Comparison of the Components of Decent Living Needs (KHL) of Palembang City with the Needs Goods and Services According to Islam

\begin{tabular}{|c|c|c|c|c|}
\hline No & $\begin{array}{c}\text { Comparative } \\
\text { Components } \\
\text { Primary Needs }\end{array}$ & $\begin{array}{c}\text { Law } \\
\text { Employment }\end{array}$ & Law Islamic & $\begin{array}{c}\text { Categories in al } \\
\text { Dharuriyatul al- } \\
\text { khams }\end{array}$ \\
\hline 1 & $\begin{array}{l}\text { Eating and } \\
\text { drinking }\end{array}$ & needs Primary & $\begin{array}{l}\text { need primary } \\
\text { (dharuruyah) }\end{array}$ & Maintenance of life \\
\hline 2 & Clothing & needs primary & $\begin{array}{l}\text { needs primary } \\
\text { (dharuruyah) }\end{array}$ & Maintenance soul \\
\hline 3 & Housing & needs primary & $\begin{array}{l}\text { needs primary } \\
\text { (dharuruyah) }\end{array}$ & Maintenance of life \\
\hline 4 & Education & need primary & $\begin{array}{l}\text { needs primary } \\
\text { (dharuruyah) }\end{array}$ & Maintenance sense \\
\hline 5 & Health & needs primary & $\begin{array}{c}\text { needs primary } \\
\text { (dharuruyah) }\end{array}$ & Maintenance soul \\
\hline 6 & $\begin{array}{l}\text { Recreation } \\
\text { and Saving }\end{array}$ & needs primary & $\begin{array}{l}\text { needs secondar } \\
\text { y (hajiyat) }\end{array}$ & $\begin{array}{l}\text { Maintenance } \\
\text { of Assets }\end{array}$ \\
\hline 7 & Worship & Needs secondary & $\begin{array}{l}\text { needs primary } \\
\text { (dharuruyah) }\end{array}$ & $\begin{array}{l}\text { Maintenance } \\
\text { religion }\end{array}$ \\
\hline 8 & Marriage & Needs secondary & $\begin{array}{l}\text { need primary } \\
\text { (dharuruyah) }\end{array}$ & $\begin{array}{l}\text { Maintenance } \\
\text { of offspring }\end{array}$ \\
\hline 9 & Transportation & Needs primary & $\begin{array}{c}\text { needs primary } \\
\text { (dharuruyah) }\end{array}$ & - \\
\hline
\end{tabular}

Source of data processed by the data comparison KEB needs to live properly with the need for goods and services according to Islam. The Mechanism for Determining the Minimum Wage in Palembang City.

According to Imam al Ghazali, economic activity is part of the social obligations of society that have been set by Allah SWT, if this is not fulfilled, world life will collapse and human life will perish. al-Ghazali formulated three reasons why someone should carry out economic activity. First, to meet the needs of the life concerned, second to make the family prosperous, and thirdly to help others in need.

From the three criteria above, it proves that a person's welfare will be fulfilled if their level of needs is fulfilled. Actually, welfare at the theoretical level has many dimensions of application, but in this case it is more focused on fulfilling the welfare of a person based on the level of his needs.

The reality in the field can be seen from several informants who were interviewed who gave explanations about Palembang City Wages for their welfare. In determining the minimum wage, the City currently has not provided welfare to workers, let alone the enactment of PP Number 78 of 2015. It is very, very limited to provide opinions to be conveyed. The current 
wage setting has provided welfare to workers related to government regulation number 78 of 2015, it is fair to provide this determination, using inflation and economic growth as well as the highest wages compared to other Sumatran provinces ".

Thus it can be concluded that some say that the welfare of workers can be achieved with the wages given by employers to them, seen from the achievement of the basic needs of life of workers that have been included in it. Even additional needs such as communication, transportation and clothing are included. However, workers who are married to see that wage determination Number 78 of 2015 has not been able to provide welfare for them, because the achievement of the needs of a decent life is only seen from the point of view of single workers.

\section{Conclusion}

The principles of wages according to the Syari'ah Economy are the principle of justice, the principle of worthiness and the principle of virtue. The provisions of the Palembang City Minimum Wage in meeting the decent living needs of workers in Palembang City according to Islam are appropriate for single workers/laborers. However, not yet for workers with families. Because the needs that are needed are increasing. seen from the principles of the Shariah Economic just give justice and virtue, while the principle of eligibility has not been seen in the setting of wages Palembang. So it is not fully directed to the principles of Shari'ah Economics.

The implication of the Palembang City Minimum Wage has not guaranteed the welfare of workers/laborers. This is because government regulation number 78 of 2015 regulates the KHL survey once in 5 years resulting in a minimum number of workers/laborers and entrepreneurs to express their opinion or desire for the necessities of a decent life. 


\section{References}

Afzalurrhman. (2000). Muhammad Sebagai Seorang Pedagang. Yayasan Swarna Bhumy.

Al-Ibrahimi, Muhammad U'qlah. Hawafijul al-A'mal Bainal Islam Wa alNazhoriyatil Wadhiyyah Maktabah ar-Risalah al-Hadisah.

al-Ghazal, Abu Hamid. Ihya Ulumuddin (2th ed). Dar an Nahdah.

al-Juhaili, Wahbah. (2005). al-Fiqh al-Islami Wa Adilatuhu (8th ed). Dar alFikr al-Mua'sshim.

-------, Wahbah. (2011). Fiqh Islam Wa adillatuhu. Gema Insani.

Anto, Hendrie. (2003). Pengantar Ekonomi Mikro Islam. Ekonosia.

An-Nabhani, Taqyuddin. Membangun Sistem Ekonomi Alternatif Perspektif Islam. In Moh. Maghfur Wachid. Risalah Gusti.

Asri, Wijayanti. (2009). Hukum Ketenagakerjaan Pasca Reformasi. PT. Sinar Grafika.

Ghazaly, Abdul Rahman., Ihsan, H Ghufron., \& Shidiq, Sapiudin. (2010). Fiqh Muamalah, Kencana.

Harun, Muhamad \& Fauziah. (2014). Konsep 'urf dalam pandangan ulama ushul fiqh (tela'ah historis). Nurani: Jurnal Kajian Syari'ah dan Masyarakat, 14(2), 1325. https://doi.org/10.19109/nurani.v14i2.107

Https://www.indozone.id/news/ yBslnO / complete-list-ump-umk -sumatera-year-2020 / read-allaccessed on 01/12/2020).

Iskandar, Muhaimin. (2004). Membajak di ladang mesin. Yawas.

Karim, Adiwarman A. (2011). Ekonomi mikro Islam (3th ed). RajaGrafindo Persada.

Khallaf, Abdul wahhab. (2000). Kaidah-kaidah hukum Islam: Ilmu ushl fiqih. In Iskandar albarsani. Moch. Tolchah, Mansoer. PT Grafindo Persada.

Moekijat. (1987). Administrasi gaji dan upah. Mandar Maju.

Paul, A. Samuelson \& William D. Nordhaus. (1986). Ekonomi (12th ed). In A.Q. Khalid. Erlangga.

Palembang Kota BARI. (1997). Pemerintah Kotamadya Daerah Tingkat II Palembang.

Riduwan. (2005). Belajar Muda Penelitian Untuk Guru Karyawan Dan Peneliti Pemula. Alfabeta.

Syaifullah, Edyson. (2008). Masyarakat Sejahtera Dalam Perspektif Islam. IRIS Foundation Press.

Sabiq, Sayyid. (1987). Fikih Sunnah. PT. Alma'arif.

Sudjana, Eggy. (2000). Bayarlah Upah Sebelum Keringatnya Kering. PPMI. 
NURANI, VOL. 21, NO. 1, JUNI 2021: 41-54 